\title{
Heat-Treatment of Crystalline Hydrated Titania Fibers and Ion-Exchange Properties for Alkaline Earth Metal Ions in Aqueous Solutions
}

\author{
Yū KOMATSU, Yoshinori FUJIKI and Takayoshi SASAKI \\ (National Institute for Research in Inorganic Materials \\ 1-1, Namiki, Sakura-mura, Niihari-gun, Ibaraki 305$)$
}

\begin{abstract}
The distribution coefficients for alkaline earth metal ions on heat-treated crystalline hydrated titania fibers were determined as a function of $\mathrm{pH}$ at $25^{\circ} \mathrm{C}$. The exchange behavior of these ions was well explained by their ion-exchange reaction with hydrogen-ion in the fibers. The ion-exchange ability of these fibers was not affected when these fibers were heat-treated between $25^{\circ} \mathrm{C}$ and about $70^{\circ} \mathrm{C}$, but the value of distribution coefficients decreased when the heat-treatment temperature exceeds $80^{\circ} \mathrm{C}$. This behavior is related to the change in the interlayer distance of crystalline hydrated titania.

[Received February 9, 1984]
\end{abstract}

\section{結晶質チタニア水和物繊維の熱処理と水溶液中のアルカリ土類 金属イオンに対するイオン交換特性}

\author{
小松優・藤木 良 規・佐々木高義
}

(無機材質研究所)

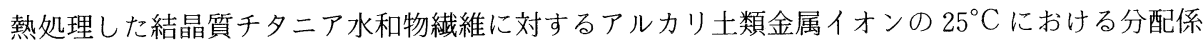
数を $\mathrm{pH}$ に対する関数として求めた。 これらのイオンの吸着挙動は, 繊維中の水素イオンとのイオ ン交換反応としてよく説明される。またこれらの瀻維の吸着能力に及ばす熱処理の影響は $70^{\circ} \mathrm{C}$ 以 下の熱処理温度ではほとんどみられないが， $80^{\circ} \mathrm{C}$ 又はそれ以上の温度では減少の傾向がみられた。 このことは, 熱処理における層間距離の変化と良く対応している. （1984 年 2 月 9 日受付）
\end{abstract}
Key-words : Heat-treated crystalline hydrated titania fiber, Adsorption of alkaline earth metal ions on inorganic ion-exchanger, Ion-exchange equilibria of alkaline earth metal ions in hydrochloric acid solutions

\section{Introduction}

The treatment of radioactive wastes has been studied by using various adsorbents ${ }^{1-3}$. The authors have also studied the adsorption properties of crystalline hydrated titania fibers from the viewpoint of the treatment of high-level liquid radiowastes. We have reported that the titania fibers adsorbed alkali metal ions ${ }^{4), 5)}$, alkaline earth metal ions $\mathrm{s}^{6,7)}$, and divalent transition metal ions ${ }^{8}$ in weak acid solutions and the ion-exchange equilibria at $25^{\circ} \mathrm{C}$ were measured. It was found that the fibers ion-exchanged cations in the order of $\mathrm{Cs}^{+}>\mathrm{Rb}^{+} \simeq \mathrm{K}^{+} \gg \mathrm{Na}^{+}>\mathrm{Li}^{+}$for alkali metal ions, $\mathrm{Ba}^{2+} \gg \mathrm{Sr}^{2+}>\mathrm{Ca}^{2+} \gg \mathrm{Mg}^{2+}$ for alkaline earth metal ions, and $\mathrm{Cu}^{2+} \gg \mathrm{Zn}^{2+}>\mathrm{Mn}^{2+} \simeq \mathrm{Co}^{2+}>\mathrm{Ni}^{2+}$ for divalent transition metal ions. These selectivity series for these cations are the same orders as that of increased ionic radii of these cation series except for divalent transition metal ions.

The ion-exchange reaction of alkaline earth metal ions on this fiber may decrease when the fibers are treated at high temperature, because hydrogen-ions in crystalline hydrated titania fibers are ion-exchanged with cations when these 
cations are entered in the fibers. It is very interesting to know the relationship between the adsorption properties and heat-resisting character of crystalline hydrated titania fibers. In the present paper, the ion-exchange of barium, strontium, calcium, and magnesium on the heattreated crystalline hydrated titania fibers was studied under the conditions similar to those of the previous work ${ }^{7}$. After the fibers were heattreated at $80^{\circ} \mathrm{C}$, the ion-exchange equilibria between these cations and hydrogen-ions are measured at $25^{\circ} \mathrm{C}$ in order to obtain further information.

\section{Experimental}

Titanium dioxide used was of $99.9 \%$ purity. All the other reagents were of an analytical grade. The aqueous solutions of alkaline earth metal ions were prepared using their chloride salts. Crystalline potassium tetratitanate fibers, $\mathrm{K}_{2} \mathrm{Ti}_{4} \mathrm{O}_{9}$, have been synthesized by the method reported previously ${ }^{9}$. The fibers of about $10 \mathrm{~g}$ were filled in a pyrex glass column (inner diameter : $25 \mathrm{~mm}$ ), and washed with about $20 \mathrm{l}$ of distilled and deionized water to eliminate a $\mathrm{K}_{2} \mathrm{MoO}_{4}$ flux. To obtain crystalline hydrated titania fibers, $1 \mathrm{~mol} \cdot 1^{-1}$ hydrochloric acid was passed through this column until the detection limit of potassium ion in the effluent by an atomic absorption method was reached. The heat-treated fibers, which were used as ion-exchanger, were prepared by heating of the crystalline hydrated titania fibers at $50^{\circ} \mathrm{C}$, $60^{\circ} \mathrm{C}, 70^{\circ} \mathrm{C}, 80^{\circ} \mathrm{C}, 90^{\circ} \mathrm{C}$, and $100^{\circ} \mathrm{C}$ for one hour.

Ion-exchange reactions were made at $25^{\circ} \mathrm{C}$. The measurements of the ion-exchange equilibria were carried out in a similar way as in the previous study $^{7)}$. The X-ray powder diffractogram was obtained by using a Rigaku Denki Diffractometer with $\mathrm{Cu} K \alpha$ radiation. A Hitachi Polarized Zeeman Atomic Absorption Spectrophotometer (Model 180-80) was used to determine the cation contents in the solution. The $\mathrm{pH}$ of the solution was measured with a TOA $\mathrm{pH}$ meter (Model HM-20E).

\section{Results and discussion}

In order to achieve the ion-exchange equilibria of alkaline earth metal ions, an agitation for ten days was necessary. The extraction of potassium from potassium tetratitanate fibers is reperesnted by the following equation:

$$
\begin{gathered}
\mathrm{K}_{2} \mathrm{Ti}_{4} \mathrm{O}_{9}+n \mathrm{H}_{2} \mathrm{O}+2 \mathrm{H}^{+} \rightarrow \\
\mathrm{H}_{2} \mathrm{Ti}_{4} \mathrm{O}_{9} \cdot n \mathrm{H}_{2} \mathrm{O}+2 \mathrm{~K}^{+}
\end{gathered}
$$

Figure 1(a) shows the weight loss of the hydrated fibers as a function of the heat-treated temperature. Figure 1(b) shows the value of $d_{200}$ spacing obtained from the strongest peak in X-ray powder diffractogram as a function of the heattreated temperature. The shape of this curve resembles to that of the curve in Fig. 1(a).

From the data in Fig.1(a), the heat-treated fibers hold interlayer water up to the temperature of about $50^{\circ} \mathrm{C}$, but a part of the water in the fibers is released under the conditions above $50^{\circ} \mathrm{C}$. By this dehydration, the interlayer distance may shrink. This facts are well explained by the data of the $d$-spacing obtained from the strongest peak, $d_{200}$ spacing, in X-ray powder diffractogram showed good coincidence with the data previously reported ${ }^{10)}$. It is known that hydrated titania fibers are crystalline materials having a layer structure which resembles the layer structure of potassium tetratitanate ${ }^{10)}$. This indicates that crystalline potassium tetratitanate fibers are changed to crystalline hydrated titania fibers by passing through the concentrated hydrochloric (a)

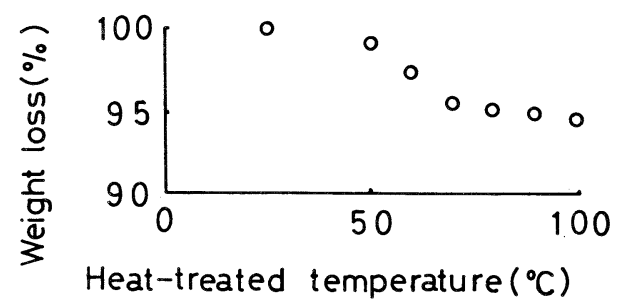

(b)

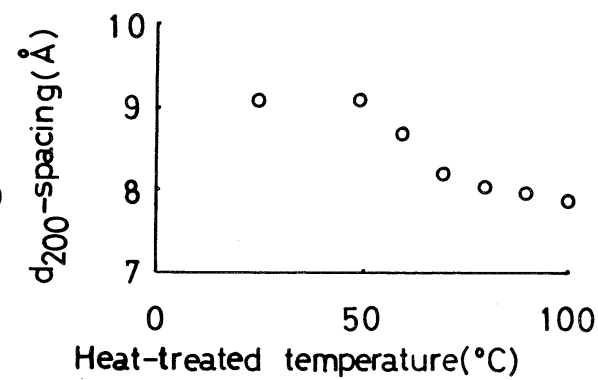

Fig. 1. (a) The weight loss of the fibers as a function of the heat-treated temperature. Heating time : One hour. (b) The values of $d_{200}$ spacing obtained from the strongest reflection peak in X-ray powder diffractogram as a function of the heat-treated temperature. 
acid solution as Eq. (1). This equation means that protons may replace potassium ions to form hydroxyl group by being attached to oxide ions in

$\left[\mathrm{TiO}_{6}\right]$ octahedra forming a layer structure. The strongest reflection peak for the (200) plane of the fibers was observed at about $10^{\circ}$ of $2 \theta$ value, and related with the interlayer distance: the larger the value of $2 \theta$, the smaller the interlayer distance.

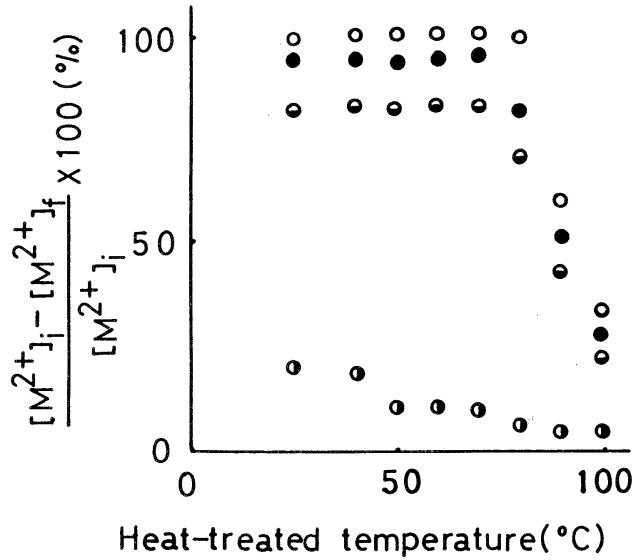

Fig. 2. The ion-exchanged amount of alkaline earth metal ions as a function of the heat-treated temperature of adsorbent at $25^{\circ} \mathrm{C}$. The ion-exchanger $(0.1 \mathrm{~g})$ is heat-treated $\mathrm{H}_{2} \mathrm{Ti}_{4} \mathrm{O}_{9} \cdot n \mathrm{H}_{2} \mathrm{O}$ (the weights were measured before heating). The aqueous solution $\left(10 \mathrm{~cm}^{3}\right)$ is contained $1 \times 10^{-4} \mathrm{~mol} \cdot \mathrm{1}^{-1}$ of each alkaline earth metal ion at initial. $\left[\mathrm{M}^{2+}\right]_{i}$ : Initial concentration of alkaline earth metal ions in the aqueous phase. $\left[\mathrm{M}^{2+}\right]_{f}$ : Final concentration of alkaline earth metal ions in the aqueous phase. $\mathrm{Ba}^{2+}(\bigcirc), \operatorname{Sr}^{2+}(\bigcirc), \mathrm{Ca}^{2+}(\ominus)$, and $\mathrm{Mg}^{2+}(\mathbf{O})$.

Figure 2 gives the ion-exchanged amount of alkaline earth metal ions as a function of the heat-treated temperature of adsorbent at $25^{\circ} \mathrm{C}$. In these experiments, each of the initial cation concentration in the aqueous phase was always kept at $1 \times 10^{-4} \mathrm{~mol} \cdot 1^{-1}$. When the fibers were heat-treated up to the temperature of $70^{\circ} \mathrm{C}$, the distribution ratio of these cations was always nearly constant. On the other hand, it was decreased when the fibers were heat-treated at $80^{\circ} \mathrm{C}$ or above. The cation exchange reaction on crystalline hydrated titania fibers can be expressed as the following equation,

$$
\begin{aligned}
& \mathrm{H}_{2} \mathrm{Ti}_{4} \mathrm{O}_{9} \cdot n \mathrm{H}_{2} \mathrm{O}_{(\mathrm{s})} \\
& \quad+x \mathrm{M}_{(\text {aq) }}^{2+} \rightleftharpoons \mathrm{H}_{2(1-x)} \mathrm{M}_{x} \mathrm{Ti}_{4} \mathrm{O}_{9} \cdot n \mathrm{H}_{2} \mathrm{O}_{(\mathrm{s})} \\
& \quad+2 x \mathrm{H}_{(\mathrm{aq})}^{+}(0<x<1)
\end{aligned}
$$

Here, the subscripts "s" and "aq" denote the solid phase and aqueous one, respectively. When these cations are incorporated in the hydrated fibers, they may occupy the same sites as those of potassium ions in the layer of $\mathrm{K}_{2} \mathrm{Ti}_{4} \mathrm{O}_{9}$. Consequently, the ion-exchanged amount of these cations on these fibers may decrease with shrinking interlayer distance.

The distribution coefficient $K d$ was calculated as :

$$
K d=\frac{\text { mole of } \mathrm{M}^{2+} \text { per } 1 \mathrm{~g} \text { of solid }}{\text { mole of } \mathrm{M}^{2+} \text { per } 1 \mathrm{~cm}^{3} \text { of solution }}
$$

Here, the weight of the solid was measured in the air-dried state.

The ion-exchange behavior of these cations on heat-treated fibers in Fig. 2 resembles to these results in Fig. 1(a) and Fig. 1(b). Though the weight loss and the shrinkage of the interlayer distance of the fibers had already been started at heating up to the temperature of $50^{\circ} \mathrm{C}$, the values of distribution coefficient did not decrease at the temperature region between $50^{\circ} \mathrm{C}$ and $70^{\circ} \mathrm{C}$. This fact may explain that the interlayer distance of the crystal was restored to the state of fiber of no heat-treatment when the fibers were contacted with the aqueous phase, and the shrinkage was not reversible under the temperature condition at $80^{\circ} \mathrm{C}$ or above. The distribution coefficient of alkaline earth metal ions for crystalline hydrated titania fibers is higher than that for the fibers heated at $80^{\circ} \mathrm{C}$. This means that the former can ion-exchange larger amount of these cations than

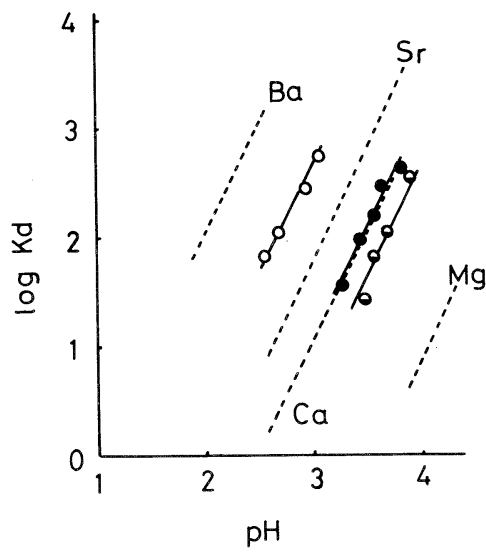

Fig. 3. Distribution coefficient (Eq. ( 3 )) of alkaline earth metal ions as a function of $\mathrm{pH}$ in aqueous phase at $25^{\circ} \mathrm{C}$. The ion-exchanger $(0.1 \mathrm{~g})$ is heat-treated $\mathrm{H}_{2} \mathrm{Ti}_{4} \mathrm{O}_{9}$. $n \mathrm{H}_{2} \mathrm{O}$ at $80^{\circ} \mathrm{C}$ (the weights were measured before heating). The aqueous solution is hydrochloric acid solution $\left(10 \mathrm{~cm}^{3}\right)$ containing $1 \times 10^{-4} \mathrm{~mol} \cdot 1^{-1}$ of each alkaline earth metal ion at initial. $\mathrm{Ba}^{2+}(\bigcirc), \operatorname{Sr}^{2+}(\mathbf{O})$, and $\mathrm{Ca}^{2+}(\Theta)$. Broken lines indicate the data of alkaline earth metal ions in Ref.7). 
Table 1. Values of $\log K d$ of alkaline earth metal ions on crystalline hydrated titania and calculated separation factors for adjacent ions $(\mathrm{pH}=3)$.

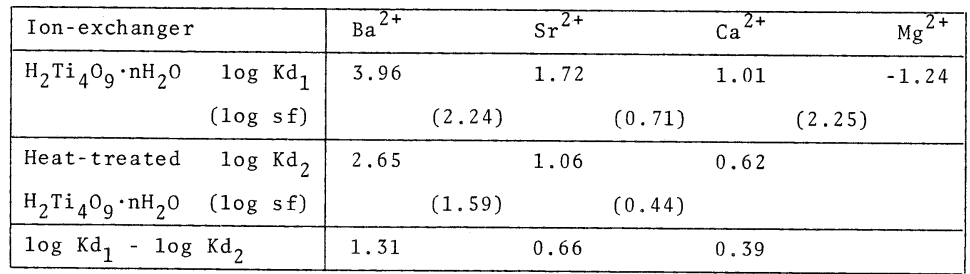

the latter because of the larger interlayer distance.

Figure 3 gives the $\log K d$ values of barium, strontium, and calcium as a function of $\mathrm{pH}$ in the aqueous phase. The slope of the log $K d$ vs. pH plot showed about +2 for these cations under the substantially constant concentration of the hydrogen-ion in the solid. This indicates that the adsorption of alkaline earth metal ions on crystalline hydrated titania fibers is well fitted with the ion-exchange reaction in Eq. (2). The values of distribution coefficient and separation factor calculated from these data are given in Table 1.

The results in Fig. 3 and Table 1 can be summarized as follows:

i) The amount of ion-exchange on the heattreated fibers at a certain $\mathrm{pH}$ is in the order of $\mathrm{Ba}^{2+}$ $>\mathrm{Sr}^{2+}>\mathrm{Ca}^{2+}$ (The amount of ion-exchange of magnesium on the fibers was very poor even in the neutral water. Then we omitted the experiment for the ion-exchange of magnesium on the fibers). This order agrees with that obtained in the previous study ${ }^{7}$, which is parallel with the increased ionic radii. ii ) The $K d$ values of the alkaline earth metal ions are smaller than those obtained by original crystalline hydrated titania fibers. iii ) The influence of the heat-treatment on the $K d$ is in the order of $\mathrm{Ba}^{2+}>\mathrm{Sr}^{2+}>\mathrm{Ca}^{2+}$. This order indicates that these cations having large ionic radii are more disturbed than those having small ionic radii. The results may be explained as follows. When the fibers were shrinked by the heat-treatment at high temperature, the interlayer free-space was decreased. Then, the diffusion of the interlayer metal ions may be restricted by the layer structure having the narrow interlayer distance. The influence of this steric effect on large metal ions is greater than that on small metal ions.

Acknowledgment The authors are very grateful to Professor Tatsuya Sekine of Science University of Tokyo for his valuable discussions during the work and to Dr. Takefumi Mitsuhashi of the Institute for assistances with the experimental work.

\section{References}

1) US-ERDA, Alternatives for managing wastes from reactors and post-fission operations in the LWR fuel cycle, ERDA-76-43 (1976).

2) M. Abe and K. Uno, Sep. Sci. Technol., 14, 355-66 (1979).

3) T. Kanno and H. Mimura, Nippon Genshiryoku Gakkai Shi, 19, 113-18 (1977).

4) Y. Komatsu and Y. Fujiki, Chem. Lett., 1980, 1525-28.

5) Y. Komatsu, Y. Fujiki and T. Sasaki, Bunseki Kagaku Section E, 31, E225-29 (1982).

6) T. Sasaki, Y. Komatsu and Y. Fujiki, Chem. Lett., 1981, 957-60.

7) Y. Komatsu, Y, Fujiki and T. Sasaki, Bunseki Kagaku Section E, 32, E33-39 (1983).

8) T. Sasaki, Y. Komatsu and Y. Fujiki, Sep. Sci. Technol. 18, 49-58 (1983).

9) Y. Fujiki and N. Ohta, Yogyo-Kyokai-Shi, 88, 111-16 (1980).

10) N. Ohta and Y. Fujiki, Yogyo-Kyokai-Shi, 88, 1-7 (1980). 